\title{
Historical Observations on Functional Reorganization
}

\author{
J.P. Mohr \\ Neurological Institute, Columbia University College of Physicians and Surgeons, New York, N.Y., USA
}

Since the beginning of Neurology, plans for therapy have been recognized to rest on efforts at establishing a diagnosis and on estimating prognosis. Absent modern in vivo imaging, for almost 150 years efforts at diagnosis were based on the tacit assumption that the lesion, whatever its cause and in either of the two cerebral hemispheres, creates more or less the same syndrome. The notion of syndromes rested on the second assumption of a fairly reliable correlation between the clinical syndrome and the locus and size of the brain lesion.

This structure-function correlation arose from examination of post-mortem material, the autopsy specimen often available not hours but years after the initial lesion. It was soon appreciated exceptions existed. Either the lesion size exceeded or was smaller than what was assumed to be the basis of the original syndrome. Attempts to explain the discrepancies led to assumptions that the lesion causing the initial syndrome had enlarged in the time from diagnosis to autopsy, or that the acute effects of the lesion affected a region larger than that found at autopsy, or something happened to improve outcome, perhaps subsidence of edema.

The initial arguments for Broca aphasia were based on the first of these notions. The large lesion in Broca's index case was assumed to have grown in the 10 years from onset, so clinicians were justified in focusing their attention on a smaller component of the lesion, located in the area therapy had predicted. Diaschesis was invented as the basis for the second effect, the initially functional disorganization caused by the acute lesion creating some sort of shock wave requiring time to subside, braining func- tion back in its wake. Subsidence in edema was among the third, the subsidence occurring in a time frame explaining the improvement. Few suggested that the brain itself was capable of some sort of software reprogramming in the hyperacute phase, computer then unknown and remodeling thought unlikely.

Objections to the expanding lesion were not long in coming. Byron Bramwell's case was talking within hours, the infarction found at autopsy being rather small but situated where the Broca area infarction was presumed to create a persisting and major speech and language disorder [1] a finding echoed almost a century later by a series of focal infarcts in Broca area [2]. Interest in this insight increased when more cases in retrospect were seen to have undergone considerable improvement and in too short to be explained as a growing lesion [3]. When viewed in the perspective of a century and with fresh cases to revive long-ignored examples, it appeared that the Broca area infarction was not the cause of Broca aphasia; a far larger lesion, one encompassing the insula and operculum, was required [4]. That initial mutism occurred and rapidly faded forced consideration of some sort of shared function or zone of compensatory tissue ipsilateral or contralateral to the focus of infarction [5]. The persisting syndromes appeared to reflect an originally larger lesion, a principle that applies to other regions as well [6].

Likewise, diaschesis, the term applied to remote effects on blood flow and metabolism [7, 8] has lost some of its initial luster [9]. Imaging has shown remote deactivation from fiber systems projecting from the acute lesion zone. However, the clinical improvements in many cases are at

\section{KARGER \\ Fax +41613061234 \\ E-Mail karger@karger.ch \\ www. karger.com

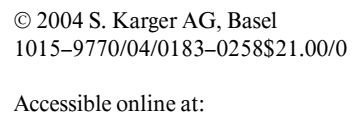

Jay P. Mohr, MD

Sciarra Professor of Neurology, Director of Stroke Center, Neurological Institute Columbia University College of Physicians and Surgeons, 710 W. 168th Street New York, NY 10029 (USA)

Tel. +1 212305 8033, Fax +1 212305 5796, E-Mail jpm10@columbia.edu 
odds with, ahead of, the timetable of fading hypometabolism and have not always affected areas inferred to mediate the improvement in function. Some evidence of remote effects from neurotransmitter pathway disruption point less to diaschesis than to dependency of one system on links to another [10] a point suggested almost a century ago by K. Goldstein.

The criticisms of the stable structure-function relationship dating back into the 19th century contain the inferences of regional or transcallosal mediation of improvement, but few of the authors went beyond the criticism to suggest the mechanisms involved. Faced with evidence of dramatic and rapid improvement in syndromes well ahead of a timetable suggested by subsidence in edema, the standard teachings of a reliably hard-wired brain [11] gradually eroded, the erosion accelerated from the earliest studies of exposed brains at surgery mapped by electrical stimulation [12-15]. Using more modern imaging of CT, now MR, the sanctity of the homunculus reflected in the syndromes of focal rolandic or capsular infarction was also violated by data from war wounds [16] and focal infarcts [17], more recently from transcranial magnetic stimulation over brain regions serving limb function before and after limb removal [18, 19] and infarction [20]. Recent work at our institution, indicating migration in function may occur [21], has shown the sensitivity of these compensatory mechanisms to relapse with pharmacologic challenge [22].

Happily, much of this is now history, consigned to library shelves, a sign of the dissatisfied gropings for insight on mechanisms of post-lesion improvement achieved prior to modern imaging. Long-dead investigators must be smiling from their graves at the progress currently underway, reviewed in some detail in this, the first such conference on the subject. After decades of struggling to gain attention to this crucial issue of brain function, it is a relief to see the field growing so rapidly. The insights from these investigations have the possibility of understanding the prognosis for a fresh brain lesion to a degree as to understand the underlying signaling systems that mediate the improvement and develop strategies to improve those destined for poor outcomes. If the current author, labeled recently as an aging enthusiast, can offer any suggestions, it is to decouple the dogma of the past from the designs of the current studies and let the data lead the work.

\section{References}

1 Bramwell B: A remarkable case of aphasia Brain 1898;21:343.

2 Mohr JP: Rapid amelioration of motor aphasia. Arch Neurol 1973;28:77-82.

3 Mohr JP: Broca's area and Broca's aphasia; in Whitaker H (ed): Studies in Neurolinguistics. New York, Academic Press, 1976, chap 6, pp 201-335.

4 Mohr JP, Pessin MS, Finkelstein S, Funkenstein $\mathrm{HH}$, Duncan GW, Davis KR: Broca aphasia: pathologic and clinical aspects. Neurology 1978;28:311-324.

5 Levine DN, Mohr JP: Language after bilateral cerebral infarctions. Role of the minor hemisphere in speech. Neurology 1979;29:927-938

6 Binder JR, Mohr JP: The topography of callosal reading pathways. A case-control analysis. Brain 1992;115:1807-1826.

7 Kempinsky WH: Spatially remote effects of focal brain injury; relation to diaschisis. Trans Am Neurol Assoc 1956;(81st Meeting):79-82.

8 Meyer JS, Shinohara Y, Kanda T, Fukuuchi Y, Ericsson A, Rodprasert P: Hemispheric blood flow and metabolism in neurological disease a note on the metabolic accompaniments of diaschisis. Trans Am Neurol Assoc 1969;94: 303-307.

9 Finger S, Koehler PJ, Jagella C: The Monakow concept of diaschisis: origins and perspectives. Arch Neurol 2004;61:283-288.
10 Tatemichi TK, Desmond DW, Prohovnik I, Cross DT, Gropen TI, Mohr JP, Stern Y: Confusion and memory loss from capsular genu infarction. A thalamocortical disconnection syndrome? Neurology 1992;42:1996.

11 Henschen SE: Klinische und Anatomische Beiträge zur Pathologie des Gehirns. Nordiska Bokhandeln, Stockholm 1920.

12 Horsley V, Schaefer EA: A record of experiments upon the functions of the cerebral cortex. Phil Trans R Soc London 1888;B179: $1-45$.

13 Penfield W, Boldrey E: Somatic motor and sensory representation in the cerebral cortex of man as studied by electrical stimulation. Brain 1937;60:389-443

14 Woolsey CN, Erickson TC, Gilson WE: Localization in somatic sensory and motor areas of human cerebral cortex as determined by direct recording of evoked potentials and electrical stimulation. J Neurosurg 1979;51:476-506.

15 Penfield W, Rasmussen T: The Cerebral Cortex of Man. New York, Hafner Publishing Company, 1968, Fig. 72

16 Mohr JP, Weiss GH, Caveness WF, Dillon JD, Kistler JP, Meirowsky AM, Rish BL: Language and motor deficits following penetrating head injury in Viet Nam. Neurology 1980;30:12731279.
17 Mohr JP, Foulkes MA, Polis AB, Hier DB, Jase CS, Price TR, Tatemichi TK, Wolf PA: Infarct topography and hemiparesis profiles with cerebral convexity infarction. The Stroke Data Bank. JNNP 1993;56:344-351.

18 Chen R, Cohen LG, Hallett M: Nervous system reorganization following injury. Neuroscience 2002;111:761-773.

19 Werhahn KJ, Conforto AB, Kadom N, Hallett M, Cohen LG: Contribution of the ipsilateral motor cortex to recovery after chronic stroke. Ann Neurol 2003;54:464-472.

20 Hallett M, Epstein CM, Berardelli A, Sackeim $\mathrm{H}$, Maccabee P: Topics in transcranial magnetic stimulation. Suppl Clin Neurophysiol 2000; 53:301-311.

21 Lazar RM, Marshall RS, Pile-Spellman J, Hacein-Bey L, Young WL, Mohr JP, Stein BM: Anterior translocation of language in patients with left cerebral arteriovenous malformation. Neurology 1997;49:802-808.

22 Lazar RM, Fitzsimmons BF, Marshall RS, Berman MF, Bustillo MA, Young WL, Mohr JP, Shah J, Robinson JV: Reemergence of stroke deficits with midazolam challenge. Stroke 2002;33:283-285. 